\title{
Lumen
}

Selected Proceedings from the Canadian Society for Eighteenth-Century Studies

\section{Hume's Imagination' Revisited}

\section{Douglas Long}

Volume 17, 1998

Theatre of the world

Théâtre du monde

URI : https://id.erudit.org/iderudit/1012385ar

DOI : https://doi.org/10.7202/1012385ar

Aller au sommaire du numéro

Éditeur(s)

Canadian Society for Eighteenth-Century Studies / Société canadienne d'étude du dix-huitième siècle

\section{ISSN}

1209-3696 (imprimé)

1927-8284 (numérique)

Découvrir la revue

Citer cet article

Long, D. (1998). Hume's Imagination' Revisited. Lumen, 17, 127-149.

https://doi.org/10.7202/1012385ar

Copyright (C Canadian Society for Eighteenth-Century Studies / Sociéte canadienne d'étude du dix-huitième siècle, 1998
Ce document est protégé par la loi sur le droit d'auteur. L'utilisation des services d'Érudit (y compris la reproduction) est assujettie à sa politique d'utilisation que vous pouvez consulter en ligne.

https://apropos.erudit.org/fr/usagers/politique-dutilisation/ 


\section{Hume's 'Imagination' Revisited}

\section{Scepticism and the Centrality of the Imagination in Hume}

J. Y. T. Greig, in his 1931 study David Hume, wrote that 'David Hume is commonly regarded as a sceptic; and the title is deserved.' He rightly observed that Hume himself accepted this 'classification.' But Greig maintained that Hume's scepticism was 'peculiar':

It had well-defined limits. It extended only to the theory of knowledge, metaphysics and its pendent [sic], natural theology, and not to ethics, politics or common life. What he doubted was the power of human reason to pronounce judgement on the highest themes. What he never doubted was the power of human instinct - or imagination, as he often called it - to conduct and regulate our everyday affairs. ${ }^{1}$

In this passage Greig raised a number of issues which have since his day continued to occupy Hume scholars. One was, of course, the precise character and extent, so to speak, of Hume's scepticism. Beginning with Norman Kemp Smith's The Philosophy of David Hume in 1941 and continuing to the present day, scholarly opinion has tended toward softening the 'well-defined limits' within which Greig sought to confine or localize Hume's scepticism. ${ }^{2}$ There can be little doubt that the impact of the adoption of a sceptical mode of thinking, both in Hume's view and in Hume's case, on philosophizing 'proper' - on matters of metaphysics and epistemology - was quite different from the impact of the adoption of such a perspective on theory or practice in 'ethics, politics or common life.' But it seems clear that Hume did both recommend and exemplify a sceptical approach to all of these areas of thought and action. Any sceptic who categorically denies the power of reason or the deludedness of uncontrolled fancy is not a sceptic - $s /$ he is a dogmatist. Hume was neither as negative about reason nor as positive about imagination as Greig suggested. But he approached both reason and imagination in a spirit of sceptical inquiry entirely worthy of ancient practitioners from Pyrrho to Carneades and Sextus Empiricus.

It is now normal practice (customary and habitual, in Hume's sense of those terms) to call Hume a 'mitigated' sceptic, or to identify in his 
thought distinguishable, if not entirely separable, elements of scepticism and naturalism. But if the term 'mitigated' is taken to mean that at some defined point in the examination of human nature and human life Hume believed that the examiner must stop inquiring sceptically, cut off all access to doubt and commit intellectually to some sort of dogmatism, then we should not use it. Scepticism, as I shall argue here, always contained the means of its own 'mitigation' in the form of recourse to a 'practical criterion' for living such as to enable the thoughtful individual to remain rooted in everyday life while facing up to the futility of philosophical system-building (or to the dangerous excesses of 'superstition' and 'enthusiasm'). 'Mitigated' scepticism is still scepticism - it is not watered down or intermittent or tactical scepticism. It is in fact 'the genuine article.' As for naturalism, why should a reliance on a non-rationalist account of 'nature' take the thinker outside the methodological boundaries of sceptical inquiry? As we shall see, reliance on nature was the first element in the classical sceptics' 'practical criterion.'

Greig's characterization of Hume's oeuvre seems to me infelicitous in a second way: his way of summarizing Hume's ideas of reason and 'instinct,' or imagination, seems to suggest that Hume was sceptical about the former but not about the latter. I would suggest rather that Hume's analyses of both reason and imagination employed the techniques classically definitive of sceptical inquiry: resistance to the lure of dogmatism, a relentlessly critical attitude toward authoritatively established systems and explanations, a constant awareness of the complex problems involved in describing or explaining even the most commonplace of events and occurrences in life, and above all an unwavering commitment to the original goal of the sceptics: to reconcile thinkers to the limits of their capacity to know with certainty the world in which they lived. Insofar as the Greek word Skeptikoi meant 'inquirer,' not 'doubter,' the extent to which Hume was a sceptic must surely depend not so much on what he may be said to have doubted as on the nature of his method of inquiry. That method was not applied in his thinking or writing in a localized or intermittent way. It grounded and pervaded every aspect of his work.

A third observation about Greig's distillation of the essence of Hume's thinking: in the summary I have quoted Grieg seems to postulate mutually exclusive areas within Hume's analysis of the life of the mind reserved for 'reason' on one hand and 'instinct' or 'imagination' on the other. I would reject 'instinct' as a synonym for 'imagination' - the word, at least nowadays, has connotations of animalism and autonomic reaction that fail to resonate with Hume's complex portrait of the workings of the human imagination. Moreover, recent authors such as Banwart have shown that important forms of what from Hume's day to ours 
has been called 'reason' involve, or simply amount to, operations of the imagination. Moreover Hume clearly understood as much. For this reason, and for those I have just sketched, I reject the idea that Hume's scepticism can be summarized in the dictum 'doubt reason; never doubt imagination.' Both reason and imagination must be subjected to sceptical analysis: if the result is that we must trust to imagination, that is surely because the imagination, properly understood, does not make claims upon our approbation or commitment as firm, as dogmatic, as those made by or in the name of reason.

A second characterization by Greig of Hume's scepticism, which follows in Greig's text shortly after the one I have just discussed, defines Hume's scepticism in terms of his attitude toward the imagination:

Positively... Hume's scepticism is defined by his submission to the imagination for guidance in all practical affairs. But ... the imagination does not serve beyond the range of human experience ... [and] This may be described as the negative definition of Hume's scepticism. ${ }^{3}$

Are we not being told, in this text, that Hume's scepticism was co-extensive with that area in human affairs in which we have just been told that he had no doubt? 'Ethics, politics and common life,' or 'practical affairs,' clearly describe areas of human endeavour in which, for Hume, the imagination plays a huge role. Are we to accept that he never subjects these areas to critical, sceptical inquiry? Surely not. Nor should we accept the claim that 'the imagination does not serve beyond the range of human experience' without important qualifications. In the sense in which it is true, this statement is tautological, relying on the assumption that the realms of experience and imagination are simply co-extensive. But there is a narrower and very familiar sense of the term 'experience' in which imagination is precisely the human capacity which takes us beyond the direct experience of the senses. Hume did not assume that imagination and experience were co-extensive. In fact his understanding of how the imagination enabled us to participate in a world much wider than that of direct sensory experience was crucial in shaping his moral, social and political thinking.

Sextus Empiricus wrote, in his Outlines of Pyrrhonism, that scepticism entailed living in accordance with 'the criterion of the sceptic discipline.' A 'criterion,' he explained, is first 'the standard one takes for belief in reality or non-reality' and secondly 'the standard of action the observance of which regulates our actions in life. ${ }^{4}$ The practical criterion of the sceptics entailed following 'the guidance of nature, the compulsion of the feelings, the tradition of laws and customs, and the instruction of the arts' (7, editor's introduction): 
It is by the guidance of nature that we are naturally capable of sensation and thought. It is by the compulsion of the feelings that hunger leads us to food and thirst leads us to drink. It is by virtue of the tradition of laws and customs that in everyday life we accept piety as good and impiety as evil. And it is by virtue of the instruction of the arts that we are not inactive in those arts which we employ. (40)

The practical criterion was, of course, not to be adhered to as dogma. It embodied the sceptics' understanding that their mode of inquiry, sceptical doubt, was cautionary without being paralyzing. Like Sextus Empiricus, Hume relied on 'the guidance of nature, ' the compulsion of the feelings,' 'the tradition of laws and customs' and 'the instruction of the arts [and sciences]' in developing his philosophy, both as it applied to epistemological and metaphysical questions and as it informed moral and political life.

P. P. Hallie has argued that the ancient sceptics wished 'to do away with philosophy itself ... to make philosophy unnecessary by helping us to restore that rogue reason and the language he uses to their home in everyday life. ${ }^{5}$ The object in all of this, 'ATARAXIA' - peace of mind or unperturbedness - was not, Hallie asserts, any kind of 'paralytic anaesthesia': 'it was peaceful living according to the institutions of one's own country and the dictates of one's own feelings, experience and common sense. ${ }^{6}$ In those famous and agonizing passages at the end of Book One of the Treatise, what is Hume the author doing if not justifying the adoption of the practical criterion of the sceptics as a basis for a tolerably honest and happy intellectual life in his time? 'I may, nay I must yield to the current of nature, in submitting to my senses and understanding; and in this blind submission I shew most perfectly my sceptical disposition and principles. ${ }^{77}$ If Hume shows a commitment to scepticism that is in any way limited or qualified, it is surely in his decision to return to the study of philosophy, to go on struggling to refine his 'sceptical reasonings.' 'Ambition ... of contributing to the instruction of mankind, and of acquiring a name by my inventions and discoveries' and the desire for the 'pleasure' of philosophic achievement: motives such as these explain, says Hume, 'the origin of my philosophy' (271). His philosophy in this sense is bounded and governed by his 'sceptical disposition and principles,' just as most philosophical reasoning is contained and even governed, surreptitiously, by the life of the imagination. For we must not fail to note that the 'understanding' to which Hume offers 'blind submission' in this passage is in fact nothing else than 'the general and more established properties of the imagination' (267).

Does the idea of a 'blind submission' to the senses and the imagination imply the abandoning of sceptical inquiry and sceptical suspension of 
commitment? Not necessarily. To 'give in,' as it were, to the senses and the imagination, in this selective sense (selective because it does not involve submission to every whim of the fancy, but only to certain 'properties' of the imaginative process) is only to accept that in the practice of life we cannot go beyond experience, as Hume famously asserted elsewhere. In the Dialogues Concerning Natural Religion, Philo (who speaks in this instance for Hume) observes that 'the more solid and more natural arguments derived from the senses and experience' surely the sort of considerations to which Hume above suggested submission - can not normally be counter-balanced by abstract reasonings of any kind, sceptical or dogmatic. The case is altered, however, when arguments based on the senses and experience are pushed too far:

it is evident, whenever our arguments lose this advantage and run wide of common life, that the most refined scepticism comes to be on a footing with them, and is able to oppose and counterbalance them. The one has no more weight than the other. The mind must remain in suspense between them: and it is that very suspense or balance which is the triumph of scepticism. ${ }^{8}$

So our submission to sense and imagination is not so 'blind' as the passage from the Treatise might suggest. When our quest for pleasure or our fear of pain or our flights of fancy 'run wide of common life,' sceptical arguments against dogmatism and extremism can preserve a balanced mentality, a suspension (or at least conditionality) of judgment, which is crucial to our stability and happiness - and to the stability and prosperity of the associations in which we live.

We may expect, if this account of the elements of scepticism and the centrality of the imagination in Hume's account of human understanding is at all accurate, that Hume's approach to inquiry, and to discourse more generally, in the fields of morals and politics will have certain important characteristics. It will seek to expose and undermine dogmatism and fancy masquerading as certainty wherever they occur. It will seek to provide a suitably sceptical account of the abstract and contingent nature of influential and established moral and political ideas. And it will, in mitigation of the destructive effects of the sceptical critique, provide a new account of the genesis of our moral and political beliefs, judgments and rules. Part II of this paper makes a necessarily brief and selective attempt to locate these characteristics in the arguments of Hume's Treatise and first Enquiry. 


\section{Some functions of 'imagination' in Hume's thought}

Very early in Book I of the Treatise, Hume postulates a relationship between our experiences and our ideas that is particularly important in the context of moral and political thought and action: 'many of our complex ideas never had impressions, that corresponded to them, and ... many of our complex impressions never are exactly copied in ideas' (3). The world of morals and politics is especially heavily populated with complex impressions (or experiences) and complex ideas. For Hume as sceptic, the relationship between experiences and ideas is from the beginning radically contingent and epistemologically suspect. Our moral and political ideas, their relationship to experience, and the very conception or recollection of experience itself are all, in the mind, byproducts of the activity of the imagination. And the imagination is not to be trusted indiscriminately, for 'the imagination is not restrain' $\mathrm{d}$ to the same order and form with the original impressions; while the memory is in a manner ty'd down in that respect, without any power of variation' (I, I, III: 9). Hume states as a 'principle,' 'the liberty of the imagination to transpose and change its ideas' [as in 'Fables' where 'Nature ... is totally confounded'] (10). And our moral, social and political ideas - our most fundamental representations of our social and ethical context as human beings - are not simply descriptions of our accumulated experiences, individually or collectively. They are powerfully evocative and influential imaginative constructs. Much of the novelty and subversiveness of Hume's moral and political thinking rested on his appreciation of the significance of this constructive activity of the human imagination.

When, in Book I, Part I, Section IV of the Treatise, Hume introduces Resemblance, Contiguity and Causality as principles which govern the 'connexion or association of ideas,' he says that their function is to render the operations of the imagination 'in some measure, uniform ... in all times and places.' The general principle of the association of ideas is 'a gentle force, which commonly prevails, and is the cause why, among other things, languages so nearly correspond to one another' (10):

'Tis plain, that in the course of our thinking, and in the constant revolution of our ideas, our imagination runs easily from one idea to any other that resembles it ... 'Tis likewise evident, that as the senses, in changing their objects, are necessitated to change them regularly, and take them as they lie contiguous to each other, the imagination must by long custom acquire the same method of thinking, and run along the parts of space and time in conceiving its objects. As to the connexion, that is made by the relation of cause and effect ... there is no relation, which produces a stronger connexion in the fancy, and makes one idea 
more readily recall another, than the relation of cause and effect betwixt their objects. (11)

It seems clear that Hume, in describing the nature of the principle of association of ideas, is in fact describing precisely those 'general and more established properties of the imagination' to which he recommends submission in the course of everyday life. If we are to be able to focus our attention on the world of experience at all, just as in focussing our vision on a particular 'scene of life,' so to speak, we must allow the natural associative tendencies of the imagination to operate - at least so long as the resulting beliefs and feelings do not 'run wide of common life' in any significant or damaging way.

Elaborating on the basic, simple model of direct causal connection assumed in the foregoing passages, Hume adds that the imagination [or fancy] also makes a strong connection between ideas when the ideas are parts of the same chain of causes - that is, where other linking causes are interposed between them. Further, two objects are causally linked in the imagination when one 'produces a motion or any action in the other' or even 'when it has a power of producing it': 'And this we may observe to be the source of all the relations of interest and duty, by which men influence each other in society, and are placed in the ties of government and subordination' (12). Clearly the imagination will form causal links among ideas in the same way in which it forms them among objects. Thus both political activities and political ideas have the same very specific epistemological roots and status. Hume was, of course, to explore 'all the relations of interest and duty' (12) here identified as the glue of political society at great length both in Book III of the Treatise ('Of the origin of justice and property') and in his Essays. The consistency of his perspective, from this very early point in the Treatise, a point at which he was preoccupied with purely philosophical issues, to essays written much later, is striking.

When Hume has added to these points a consideration of complex ideas and of general and particular ideas, he states that he will have presented 'the elements of this philosophy' (13). It is a philosophy which recommends submission, in thought, in the practice of common life, and in the examination of morals and politics, to those general properties of the imagination which enable us to impose or elicit coherence in the world of human experience. As we shall see, it is in Hume's view only by virtue of the constructive powers of the imagination that we are able to arrive at ideas of self, of soul, of substance or of commonwealth.

In Treatise I, IV, Section II, 'Of scepticism with regard to the senses,' Hume argues that such belief as we maintain in 'the continu'd and distinct existence of body ... must be entirely owing to the IMAGINA- 
TION' (193, emphasis Hume's). We are only able to 'entertain this opinion of the continu'd existence of body' because

the imagination, when set into any train of thinking, is apt to continue, even when its object fails it, and like a galley put in motion by the oars, carries on its course without any new impulse ... Objects have a certain coherence even as they appear to our senses; but this coherence is greater and more uniform, if we suppose the objects to have a continu'd existence; and as the mind is once in the train of observing an uniformity among objects, it naturally continues, till it renders the uniformity as compleat as possible. (198)

The imagination has, then, a sort of cognitive momentum. Without such a tendency to emphasize continuity and uniformity in our experiences, it would be much harder for individuals to 'stay on course' through life. The diversity and discontinuity of our sensations and perceptions would be highly disorienting. One is strongly reminded, at this point, of Adam Smith's important essay on 'The Principles which lead and direct Philosophical Enquiries; illustrated by the History of Astronomy. ${ }^{\prime 9}$ Smith upheld in that text Hume's belief in the importance of the imagination in preventing what modern psychologists might call cognitive dissonance from disorienting the individual resident of turbulent commercial societies. But he gave to Hume's argument about the momentum of the imagination a different twist, emphasizing the difficulty of dealing with those situations in which the imagination could not manage to smooth out the sequence of one's experiences of the world. The problem, as he put it, was

That the imagination feels a real difficulty in passing along two events which follow one another in an uncommon order ... If it attempts to attend beyond a certain time to a long series of this kind, the continual efforts it is obliged to make, in order to pass from one object to another, and thus follow the progress of the succession, soon fatigue it, and if repeated too often, disorder and disjoint its whole frame. (II. 10:43)

The effects of such a disordered experience of life, Smith wrote, might range from 'confusion and giddiness' to 'lunacy and distraction.' Smith offered two possible remedies for such a debilitating disorientation. First, in growing to maturity in a civilized society and acquiring 'the soundest judgment,' an individual's imagination might as a matter of course 'have acquired those habits, and that mold, which the constitution of things in this world necessarily impress upon it' (43) - a solution to the problem of imaginative dissonance (so to speak) highly reminiscent of Hume's. But Smith also argued, unlike Hume, that it was the primary 
function of philosophy, as 'the science of the connecting principles of nature' (II.12:45), to 'allay this tumult of the imagination, and restore it, when it surveys the great revolutions of the universe, to that tone of tranquillity and composure, which is both most agreeable in itself, and most suitable to its nature.' (46) It would seem that a crucial function which Hume ascribed to the momentum of the imagination itself, Smith pointedly ascribed only to the therapeutic qualities of scientific and philosophical inquiry.

Once again, Hume took up a position almost antithetical to the one Smith was to adopt when he examined the role of the imagination in sustaining the idea of personal identity. The idea of identity, he claimed, rests on an epistemological mistake: we 'confound' the idea of identity with the idea of a series of closely related but distinct objects. Why? Because of the 'biass' of the imagination. It sees so much resemblance between identity and swift succession of related objects that it substitutes the idea of one for that of the other:

[I]n order to justify to ourselves this absurdity, we often feign some new and unintelligible principle that connects the objects together, and prevents their interruption or variation. Thus we ... run into the notion of a soul and self, and substance. (I, IV, VI:254)

Smith never spoke of 'feigning' principles in his essay on the history of astronomy. Rather, he spoke of the discovery of links really connecting phenomena but which could only be brought to light by properly conducted philosophical enquiries. Nor did Smith concede the 'unintelligibility' of such principles. Nor did he rest our ideas of identity and materiality on such feigning. In areas such as these, the differences between Smith's neo-Stoicism and Hume's scepticism can be very substantial indeed. Nonetheless, both Hume and Smith hold that imagination is the pivotal capacity in the process whereby individuals sustain a notion of personal identity amid the flux of experience, and is also the capacity which enables us to believe in the continuity and coherence of the external world.

Imagination has other functions for Hume, more specific perhaps, but no less essential to the development of our moral and political ideas than those identified so far. It is the imagination, for example, which permits us 1) to form judgments as to the plausibility of ideas and arguments presented to us by others, and 2) to form generalizations about experience which 'carry our view beyond' the narrow scope of present experience: 
[Experience and Habit] conspiring to operate upon the imagination, make me form certain ideas in a more intense and lively manner, than others, which are not attended with the same advantages. Without this quality [imagination] by which the mind enlivens some ideas beyond others (which seemingly is so trivial, and so little founded on reason) we could never assent to any argument, nor carry our view beyond those few objects, which are present to our senses. (I, IV, VII:265)

It is the imagination which endows our ideas with their 'vivacity,' and it is on this vivacity that memory, sense and understanding all depend. (265)

The array of ideas and mental processes which depends upon the imagination in Hume seems almost unbounded. But for the purposes of the present paper I shall briefly examine three processes which seem to me to be fundamental pillars of all moral and political thought: belief, judgment and rule-making. 'The whole nature of belief' is nicely summarized in the Enquiry Concerning Human Understanding. ${ }^{10}$ The context is revealing: Section IV having laid out 'Sceptical Doubts concerning the Operations of the Understanding,' Section V offers a 'Sceptical Solution of these Doubts' rather more positive but at the same time more tentative in tone than that suggested at the end of Book I of the Treatise. The imagination, Hume asserts,

has the command over all its ideas, and can join and mix and vary them, in all the ways possible ... But as it is impossible that this faculty of imagination can ever, of itself, reach belief, it is evident that belief consists not in the peculiar nature or order of ideas [which are controllable through imagination], but in the manner of their conception, and in their feeling to the mind ... And in philosophy, we can go no farther than assert, that belief is something felt by the mind, which distinguishes the ideas of the judgement from the fictions of the imagination. $(\mathrm{V}$, II:49)

What is the exact relationship here between judgment and imagination? David Miller has addressed this precise question in his admirable study of the philosophical basis of Hume's political ideas, Philosophy and Ideology in Hume's Political Thought (1981). Hume's theory of judgment, Miller writes, has three main features which will prove to be of significance for his social and political thought. First, as part of Hume's science of man and of mind, 'he has given an account of how judgements are made. This account makes primary reference to the imagination and its various natural propensities.' Such propensities include, for example, the quality of imaginative 'momentum' referred to earlier in this paper. 'Second,' says Miller, Hume has shown that 'the judgements thus made 
are incapable of being rationally vindicated.' As Hume showed at the end of Book I of the Treatise, attempts at rational vindication end in a total or nihilistic scepticism, which can only be relieved by the adoption of the classical sceptics' practical criterion: 'recognizing that we are obliged by nature to believe and judge in the normal way.' Miller's third observation about Hume's theory of judgment seems to me to be particularly illuminating as to the nature of moral, social and political theories which try to offer judgments of superior quality, or to provide means of improving the quality of our typical judgments, in moral, social and political matters. Can such judgments be improved? Yes, but not by 'replacing non-rational judgement by rational judgement':

Improvement can only take place within the limits set by the natural workings of the mind. The permanent principles of the imagination can be employed to counteract the fluctuating ones. It is not a matter of judging in a way fundamentally different from the vulgar consciousness, but of employing principles recognized by that consciousness in order to correct it. ${ }^{11}$

'The permanent principles of the imagination' - Hume's 'general and more established properties of the imagination ${ }^{12}$ - must structure our judgments. And when we combine the activity of improving those judgments with the exercise of another Humean capacity based on imagination, namely the all-important capacity for 'sympathy,' we have the basis for the development of general rules. In the operation of sympathy (which Hume described in a letter to Adam Smith as the 'lynch-pin' of his system) the key step is the conversion of an idea (say, of suffering) into an actual impression. It is the imagination which enables us to do this, says Hume. ${ }^{13}$ Thus we can participate vicariously, imaginatively, in the pleasures and pains (i.e the 'impressions of sensa-

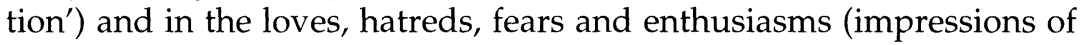
reflection) - of others. This is indispensable to the development of an idea particularly central to the deploying of Hume's social and political theories in the second Enquiry - the idea of utility. No Benthamic calculus is implied here, but what is postulated is the communicability of pleasure, pain and other experiential phenomena such as will motivate persons to make fundamental social and political judgments, based on sympathy and imaginative belief, about their interests. In the case of the rules of property, Hume says, 'there are, no doubt, motives of public interest for most of the rules ... but still I suspect, that these rules are principally fix'd by the imagination. ${ }^{14}$ Only the imagination, which, as observed above, permits us to extend the range of our ideas beyond the narrow compass of our direct personal experience, can make it possible for a sense of public interest to emerge to counterbalance the predomi- 
nance in every individual of self-interest. We are creatures of 'selfishness and confin'd generosity, ${ }^{\prime 15}$ capable of conjuring up, in sentiment and imagination if not through abstract reason, 'a general sense of common interest; which sense all the members of the society express to one another, and which induces them to regulate their conduct by certain rules' (III, II, II:490). Thus arise the 'conventions,' such as justice, property and the keeping of promises, on which political society is built.

The fundamental principles of political society rest upon the twin pillars of political judgment and the sense of interest. Judgment and the sense of interest rest in turn on our beliefs about other persons and our social context generally, and our beliefs about our own 'selves.' And all such beliefs are formed and lodged in the imagination. When our imaginings 'run wide of common life' and prompt us to deluded (say, enthusiastic or superstitious or dogmatic) beliefs or behaviour, we must have recourse not to rationalist constructs but to the moderating effect of sceptical arguments aimed at softening our beliefs and judgments, and thus restraining our extremist actions. The distinctive flavour of Hume's political thought - and especially the 'conservative,' anti-innovative thrust which sometimes surfaces within it - has its roots in his treatment of the imagination and the implications he derived therefrom.

\title{
III Hume's 'Secularized Imagination' as a key element in early modern social, moral and political thinking
}

\author{
'Imagination is the eye of the soul.' - Joubert
}

'Thus we feign the continued existence of the perceptions of our senses ... and run into the notion of a soul, and self, and substance.'

(Treatise, I,IV,VI, 'Of Personal Identity')

Between the medieval heyday of the 'apocalyptic imagination ${ }^{\prime 16}$ and the intense spirituality expressed in the burgeoning 'constructive imagination' of the Romantics lay a period during which sceptics and humanists, adherents to the new science of Bacon and the somewhat protean new philosophy which was inextricably interwoven with it, attempted to refurbish - or perhaps rather refurnish - the human imagination. I would not presume here to say when or how this process began, but something of its nature can be seen in the way in which the 'scene' viewed by the imagination is secularized in Hume: the imagination in Hume ceases to be the individual's epiphanic window on spiritual reality; it ceases to be the 'eye of the soul,' and is instead the individual's eye on the soul. The hierarchy unveiled in the imagination is no longer 
that of Jacob's ladder or the Great Chain of Being, but that formed by the 'dispositions,' 'impressions' and 'ideas' which compete for control of the 'character' of one's personal identity amid the 'constant changes of its parts.' In Hume, as in his intellectual successor Adam Smith, the imagination is our most powerful navigational instrument amid the turbulence of commercial society. Correspondingly, commercial society, displacing the divine spiritual or natural order, becomes the amphitheatre of the imagination.

Signs of the beginnings of the shift I am talking about can certainly be seen in the impish naturalism of Michel de Montaigne's essay 'Of the power of the imagination':

A strong imagination creates the event, say the scholars. I am one of those who are very much influenced by the imagination. Everyone feels its impact, but some are overthrown by it. Its impression on me is piercing. And my art is to escape it, not to resist it ... I do not find it strange that imagination brings fevers and death to those who give it a free hand and encourage it. ${ }^{17}$

Hume, like Montaigne, was quite reconciled to the creation of events by the human imagination - he wrote a history of England, after all! And he shared Montaigne's belief that everyone must feel the imagination's impact. The question is: how to respond? Resistance is pointless Greig's statement that Hume did not doubt the power of the imagination is certainly right as far as it goes. But there must be some escape, some source of balance or perspective - imagination must not be given a totally free hand. And sceptical principles allow for an escape - a mitigation of the extreme and oppressive impact of the unbridled fancy. Hume found it possible, even necessary, once his escape had (at the end of Treatise, I) been effected, to return to philosophy (to 'refined' sceptical philosophizing, to be sure). Montaigne, by way of contrast, seems at first to have called for a sort of naturalistic 'ignorance' and 'negligence':

In this universe of things I ignorantly and negligently let myself be guided by the general law of the world. I shall know it well enough when I feel it. My knowledge could not make it change its path; it will not modify itself for me. It is folly to hope it, and greater folly to be troubled about it, since it is necessarily uniform, public and common.

Philosophical inquiries and meditations serve only as food for our curiosity. The philosophers ... refer us to the rules of Nature; but these have no concern with such sublime knowledge. The philosophers falsify them and show us the face of Nature painted in too high a color, and too sophisticated, whence spring so many varied portraits of so uniform a subject ... The more simply we trust to 
Nature, the more wisely we trust to her. Oh, what a sweet and soft and healthy pillow is ignorance and incuriosity, to rest a well-made head! ${ }^{18}$

In the end, Montaigne seems to have arrived at a sort of cat-and-mouse game of intellect and imagination:

Now I treat my imagination as gently as I can, and would relieve it, if I could, of all trouble and conflict. We must help it and flatter it, and fool it if we can. My mind is suited to this service; it has no lack of plausible reasons for all things. ${ }^{19}$

Hume's escape route, his strategy for avoiding being 'overthrown' by the imagination, involved less literary playfulness and more actual philosophizing than Montaigne's. But both men seem to have sought a way to live, as the classical sceptics recommended, 'appropriately.'20

In his excellent introduction to the new Cambridge University Press edition of Pufendorf's On the Duty of Man and Citizen, James Tully argues that the first objective of the authors who constituted the natural jurisprudence 'school' was 'to cleanse natural law of its grounding in the Aristotelian and Thomistic concept of nature as a purposeful realm ordered by intrinsic teleological dispositions. ${ }^{21}$ The 'new science' associated with Bacon, Galileo, Hobbes, Gassendi, Descartes and others (its influence on Hume is abundantly clear) was thought by the likes of Grotius and Pufendorf to provide the required new grounding for natural law: 'The philosophers of the new natural sciences advanced a concept of nature as a non-purposive realm of atoms on which God imposes, by an act of will, motion and an extrinsic order of efficient causes or regularities. ${ }^{, 22}$ (xvii) In the view of scholars such as Tully and Richard Tuck, this was a decisive step away from classicism and toward modernity. Hume carried this transition a major step further by abandoning reference to, and belief in, the constructive role of the Divine will, and by substituting 'human nature' for 'natural law' as the moral lodestone of his system. For the crucial agency of the Divinity he substituted the constructive power of the human imagination.

Thomas Hobbes was of course an influential proponent of both a new philosophy and a new science in the sense we have been examining here. And it is noteworthy that Hume was ambivalent about Hobbes. He recognized Hobbes's standing as a celebrated philosopher 'both at home and abroad,' but was decisive in his rejection of him as, in effect, a secular dogmatist:

No English author in that age was more celebrated both at home and abroad than Hobbes: In our time, he is much neglected: A lively instance how precarious [are] all reputations, founded on reasoning and philosophy! ... 
Hobbes's politics are fitted only to promote tyranny, and his ethics to encourage licentiousness. Though an enemy to religion, he partakes nothing of the spirit of scepticism; but is as positive and dogmatical as if human reason, and his reason in particular, could attain a thorough conviction in these subjects. ${ }^{23}$

Hobbes's treatment of imagination in Leviathan (Bk. I Chap. 2) contains many of the elements of a Humean analysis, but lacks all sceptical sense of contingency or tentativeness:

For after the object is removed, or the eye shut, we still retain an image of the thing seen, though more obscure than when we see it. And this is it, the Latines call Imagination, from the image made in seeing; and apply the same, though improperly, to all the other senses. But the Greeks call it Fancy; which signifies appearence, and is as proper to one sense, as to another. IMAGINATION therefore is nothing but decaying sense ... Imagination and Memory are but one thing, which for diverse considerations hath diverse names ... Much memory, or memory of many things is called Experience. ${ }^{24}$

This analysis begins with the same components as are deployed by Hume in Book I of the Treatise, but ends by calling imagination nothing but decaying sense, and identifying it with memory. Such conclusions were too dogmatically mechanistic and materialist for Hume. The sense of similarity and continuity as between Hobbes and Hume is stronger if one looks at their arguments against the backdrop not of the 'new science,' but of the tradition of rhetoric. David Johnston, in his work on 'the rhetoric of Leviathan,' compares Hobbes's use of rhetorical strategies in his texts to those recommended by Sir Philip Sidney in his Defense of Poetry:

Sidney's argument rests upon ... the thesis that the visual image, even if conveyed in words as a 'speaking picture,' is capable of making a far deeper, more striking impression than any merely verbal argument or precept. In effect his argument is that the visual is far more powerful than the merely conceptual, that the image is more forceful and effective than the proposition. And Hobbes, in his own discussion of elocution and style, concurs absolutely. Borrowing from Plutarch, he argues that Thucydides excels in perspicuity, for he 'aimeth always at this: to make his auditor a spectator, and to cast his reader into the same passions that they were in that were beholders.' Perspicuity ... is for Hobbes the first and most important of all the elements of style. ${ }^{25}$

Both Hobbes and Hume grasped that 'the visual is more powerful than the merely conceptual ... the image is more forceful and effective than the proposition' to modern readers. A number of striking and engrossing images are indeed conjured up by the text of the Treatise, and I propose to examine one of them as a way of illustrating the relationship 
between imagination as treated of in Hume and in the writings of his great friend Adam Smith. Hume and Smith each provide the reader with one particularly powerful visual image designed to characterize in an illuminating way the inner being, or 'soul,' of the individual. Hume's image occurs in the course of the well-known section of the Treatise on 'personal identity':

I cannot compare the soul more properly to any thing than to a republic or commonwealth, in which the several members are united by the reciprocal ties of government and subordination, and give rise to other persons, who propagate the same republic in the incessant changes of its parts. And as the same individual republic may not only change its members, but also its laws and constitutions; in like manner the same person may vary his character and dispositions, as well as his impressions and ideas, without losing his identity. (I, IV, VI, 'Of Personal Identity', 261)

The emphasis here is on continuity amid constant change: the identity is sustained despite 'incessant changes of its parts,' of 'character,' 'dispositions,' 'impressions' and 'ideas.' This is a sceptic's view of the nature of identity. Smith's image of the imaginative 'interior' of the individual showed more of the influence of Stoicism with its emphasis on 'self-command.' Smith's view is well laid out in a letter to Gilbert Elliot in which he is discussing a - possibly the - bone of contention between himself and Hume: the idea of 'sympathy.' Smith told Elliot that he had worked out an analysis of sympathy that had 'quite discomfitted' Hume. Hume had complained that Smith seemed to want to consider all sympathy as pleasurable, whereas sympathetic understanding of misery would seem to be itself a form of unhappiness. Smith replied that sympathy fully understood involved two processes: a sort of vicarious participation in the sentiments of the observed party, which he conceded might be pleasurable or painful depending on what was observed, and secondly,

the emotion which arises [in 'the Spectator'] from his observing the perfect coincidence between this sympathetic passion in himself and the original passion in the person principally concerned. This last emotion, in which the Sentiment of approbation properly Consists, is always agreable and delightful. The other may be either agreable or disagreable, according to the nature of the original passion. ${ }^{26}$

Such sympathetic sensibility may be a necessary condition of our ability to make moral assessments of our actions, but only the constructive imagination can provide sufficient conditions for moral judgment: 
We soon learn, therefore, to sett up in our own minds a judge between ourselves and those we live with. We Conceive ourselves as acting in the presence of a person quite candid and equitable ... who is neither father, nor Brother, nor friend, either to them, or to us; but is meerly a man in general, an impartial Spectator who considers our conduct with the same indifference with which we regard that of other people.

... if the man within condemns us, the loudest acclamations of mankind appear but as the noise of ignorance and folly ... The weak, the vain and the frivolous, indeed, may be mortified by the most groundless Censure or elated by the most absurd applause. Such persons are not accustomed to consult the judge within concerning the opinion which they ought to form of their own conduct ... When the world injures them, therefore, they are incapable of doing themselves Justice and are in consequence the Slaves of the world. (54-5)

Hume turned the imaginative eye of the sceptic inward and discovered the turbulence of a commonwealth within the boundaries of a single personal identity. Smith turned the eye of the stoic inward and discovered the voice of conscience. Smith argued that those who did not locate within themselves this source for moral judgments would simply remain 'slaves of the world.' Hume tried to provide, through maintenance of a sceptical suspension of judgment, a counterbalance to the potentially overpowering force of unbridled 'fancy.' Both authors provided vivid and innovative secular imageries of the individual attempting to identify 'himself' and to navigate successfully through the unprecedentedly turbulent world of emerging commercial society by achieving tranquillity and composure of the imagination.

Smith went beyond the question of moral judgments in his portrayal of the 'Impartial Spectator' in his letter to Elliot, extending his analysis to the idea of social vision: our imaginative 'view' of our social context is the precursor of our moral judgments about it and about ourselves at least in the secularized theory of Hume and Smith. Smith's thinking on this theme provides his response to the work of Bishop Berkeley:

It is only by consulting this judge within that we can see whatever relates to ourselves in its proper shape and dimensions, or that we can make any proper comparison between our own interests and those of other men.

As to the eye of the body objects appear great or small, not so much according to their real dimensions, as according to the nearness or distance of their situation; so do they likewise to, what may be called, the natural eye of the mind: and we remedy the defects of both these organs pretty much in the same manner.

I can form a just comparison between [large and small, near and distant] objects ... in no other way, than by transporting myself, at least in fancy, to a different 
station, from whence I can survey both at nearly equal distances, and thereby form some judgement of their real proportions. Habit and experience have taught me to do this so easily and so readily, that I am scarce sensible that I do it; and a man must be, in some measure, acquainted with the philosophy of vision, before he can be thoroughly convinced, how little those distant objects would appear to the eye, if the imagination, from a knowledge of their real magnitudes, did not swell up and dilate them. (56, italics mine)

From these insights Smith seems to have derived a Humean conclusion about the preeminence of self-interest as a motivating force in human action. Just as Hume postulated selfishness and limited generosity as the relevant human inclinations, Smith tempered individual selfishness with a more sociable element: the sense of propriety. Smith made a great deal of the idea of propriety in Book I of the Theory of Moral Sentiments, a work published just before he wrote to Elliot in 1759. The kernel of the idea of propriety is clearly present in the part of the Elliott letter which makes the sense of propriety the key to the achievement of stoic 'magnanimity and firmness,' and, ultimately, justice:

to the selfish and original passions of human nature, the loss or gain of a very small interest of our own, appears to be of vastly more importance ... than the greatest concern of another with whom we have no particular connection. His interests as long as they are surveyed from this station, can never be put into the ballance with our own ... Before we can make any proper comparison of those opposite interests we must change our position ... Here too habit and experience have taught us to assume this station so easily and so readily that we are scarce sensible that we assume it ... [thus] the sense of propriety and justice ... correct the other wise natural inequality or our sentiments ... from this Station only ... we can learn the great lesson of Stoical magnanimity and firmness. (56)

But note that there is a clear echo in Smith's text of Hume's original concern with the way in which our fancy (here our 'passions') may 'run wide of common life' and carry us to extremes of unrealistic action:

Even the judge within is often in danger of being corrupted by the violence and injustice of our selfish passions, and is often induced to make a report very different from what the real circumstances of the case are capable of authorizing.

In his essay 'Of the External Senses,' concerned primarily with Bishop Berkeley's New Theory of Vision (1709), Smith compared language to vision: 
The objects of sight, as Dr. Berkley [sic] finely observes, constitute a sort of language which the Author of Nature addresses to our eyes ... As, in common language, the words or sounds bear no resemblance to the things which they denote, so, in this other language, the visible objects bear no sort of resemblance to the tangible object which they represent. ${ }^{27}$

Smith emphasized the distinction, in vision, between the 'visible object,' which is the actual pattern of shape and shading formed on the retina of the eye, and the 'tangible object.' The correspondence between visible and tangible objects in vision, while very imperfect and potentially deceptive, is, he says, 'much superior to that which takes place either between written and spoken language' or between spoken language and the ideas or meanings which it suggests':

The language which nature addresses to our eyes, has evidently a fitness of representation, an aptitude for signifying the precise things which it denotes, much superior to that of any of the artificial languages which human art and ingenuity have ever been able to invent. (62:158)

What is significant here is not that seeing is better than describing, but that neither seeing nor describing can bridge the gap between representation, or 'visible object' and reality, or 'tangible object.' Improved vision, he adds, like improved language, depends upon 'observation and experience' more than on 'reason': both are matters of acquiring the proper perspective, which only the practice of living can bestow (63:158; 74:163). Moreover, improved language, like improved vision, is essential to 'security,' especially in a turbulent transactional society:

The benevolent purpose of nature in bestowing upon us the sense of seeing, is evidently to inform us concerning the situation and distance of the tangible objects which surround us. Upon the knowledge of this distance and situation depends the whole conduct of human life, in the most trifling as well as in the most important transactions. Even animal motion depends upon it; and without it we could neither move, nor even sit still, with complete security. (60:156)

The 'eye of the imagination,' the 'sense of seeing,' was as crucial to Hume as to Smith. For both authors, vision in a very broad sense was desperately needed if individuals were to sustain a sense, however fictive, of 'self,' 'soul' and/or 'substance' in modern political society. Upon such a sense, Smith said, depends 'the whole conduct of human life.' When Hume had earlier written that the power of the imagination to link objects together in causal chains was 'the source of all the relations of interest and duty, by which men influence each other in society, and 
are placed in the ties of government and subordination, ${ }^{28}$ he had been moved by the same concern for the stability and coherence of social and political life in commercial society which motivated Smith.

With the appearance of the militantly atheistic utilitarian system of Jeremy Bentham the secularization of the individual imagination in the context of modern commercial life was taken to its most extreme limits. What Pyrrhonism was to Scepticism, Benthamism was to the 'science of man' in the post-Baconian tradition. In his essays on Bentham and Coleridge, J.S. Mill seems to have been acutely aware of Romanticism as a sort of 'intellectual backlash' against Benthamic impoverishment of the imagination. Hume had made room in his 'science of man' for the role of the imagination in taking the individual beyond the narrow limits of her own immediate hedonistic experiences. Bentham based his 'science of man' on a basic proposition which he considered 'obvious and incontestible': that 'physical sensibility [was] the ground of law. ${ }^{29}$ This went far beyond anything Hume or Smith had ever imagined arguing. Although Bentham claimed to be a keen supporter of Hume's work in Treatise Bk. III, and although he dedicated his Defense of Usury to Smith, his doggedly systematic hedonism was of a kind which might well have caused Hume, had he had occasion to consider the matter, ${ }^{30}$ to identify Bentham as a greater 'secular dogmatist' than Thomas Hobbes. In the essay on Bentham, J.S. Mill identified two major 'disqualifications' of Bentham as a philosopher. The seond of these was 'the incompleteness of his own mind as a representative of universal human nature':

In many of the most natural and strongest feelings of human nature he had no sympathy; from many of its graver experiences he was altogether cut off; and the faculty by which one mind understands a mind different from itself, and throws itself into the feelings of that other mind, was denied him by his deficiency of Imagination.

With Imagination in the popular sense, command of imagery and metaphorical expression, Bentham was, to a certain degree, endowed. For want, indeed, of poetical culture, the images with which his fancy supplied him were seldom beautiful, but they were quaint and humorous, or bold, forcible, and intense: passages might be quoted from him both of playful irony, and of declamatory eloquence, seldom surpassed in the writings of philosophers. The Imagination which he had not, was that to which the name is generally appropriated by the best writers of the present day; that which enables us, by a voluntary effort, to conceive the absent as if it were present, the imaginary as if it were real, and to clothe it in the feelings which, if it were indeed real, it would bring along with it. This is the power by which one human being enters into the mind and circumstances of another. 
Without it nobody knows even his own nature, further than circumstances have actually tried it and called it out; nor the nature of his fellow creatures, beyond such generalizations as he may have been enabled to make from his observation of their outward conduct. ${ }^{31}$

In this passage Mill captured perfectly what was lost in the transition from the secularized but still powerfully creative imagination of Hume to the utterly prosaic and mechanized imagination in Bentham. The Romantic reaction seems in retrospect to have been inevitable. But it was not a reaction against Humean scepticism. It was a radical rejection of Benthamic dogmatism. It was a rejection of the sort of spirit exemplified in James Mill's analysis of the imagination in his Analysis of the Phenomena of the Human Mind, when Mill wrote of 'the perverting influence, or bias, of the feelings in matters of truth and falsehood, or in works of utility':

When the true and the useful, instead of being determined by their own ends, or their proper criteria, are swayed by extraneous emotions - giving birth to mythical or fictitious creations - we have the corrupting substitution of Imagination for Reason in men's judgments and opinions. ${ }^{32}$

Where Hume had attacked the corrupting substitution of reason for imagination in human judgments and opinions, the thrust of the Benthamite utilitarians was in just the opposite direction. The ground was ready for the Romantic reaction. Hume's perspective on social and political thinking was to come into favour again, with the late twentieth century's rejection of the utilitarians' 'constructivist' rationalism and the rise to immense political influence of a thinker (F.A. Hayek) whose views were said to be a reflection of his scepticism about the capacity of individuals and communities to produce defensible rational theories on subjects such as distributive or social justice. Social justice, said this student of Hume, is a 'mirage'.

And in this fashion the oscillation between scepticism and dogmatism that began with the debate between Pyrrhonists and Platonists in the Academy has continued to this very day. Few thinkers in the entire history of this great debate have shown a more profound grasp of the importance of the relationship between doubt and certainty, or between imagination and reason, than David Hume.

\section{DOUGLAS LONG}

University of Western Ontario 


\section{Endnotes}

1 J. Y. T. Greig, David Hume (London: Jonathan Cape, 1931) 14.

2 For current opinion see, for example, Mary Banwart, Hume's Imagination (New York: Peter Lang, 1994) ch. 5.

3 Grieg, David Hume, 16.

4 Outlines of Pyrrhonism, Book I, Chap. XI 'The Criterion of Scepticism,' in Sextus Empiricus: Selections from the Major Writings on Scepticism, Man and God, ed. P. P. Hallie, trans. S. G. Etheridge (Indianapolis: Hackett, 1985) 39-40. Future references to this work will appear within parentheses in the text.

5 Sextus Empiricus 39n.

6 Ibid., 7.

7 David Hume, A Treatise of Human Nature, ed. L. A. Selby-Bigge, 2nd ed. (Oxford: Clarendon Press, 1978) I, IV, VII: 269. Further references to this work will appear within parentheses in the text.

8 Cited in David Miller, Philosophy and Ideology in Hume's Political Thought (Oxford: Clarendon Press, 1981) 36, n33.

9 Adam Smith, Essays on Philosophical Subjects, ed. W. P. D. Wightman and J. C. Bryce (Oxford: Clarendon Press, 1980) 31-105. Future references to this work will appear within parentheses in the text.

10 Enquiries Concerning Human Understanding and Concerning the Principles of Morals, ed. L. A. Selby-Bigge, 3rd ed., rev. P. H. Nidditch, 1st Enquiry V, II:48.

11 Miller 39. See also 38.

12 Treatise, I, IV, VII:267.

13 Treatise, Bk. II, ‘Of the Passions,' Pt. II, 'Of Love and Hatred,' Sec. VIII, 'Of Compassion,' 371. See also 385-6.

14 Treatise, Bk. II, Pt. II, ‘Of Justice and Injustice,' Sec. III, ‘Of the rules, which determine property,' 504, $\mathrm{n} 1$.

15 Treatise, III,II,II, 'Of the origin of justice and property,' 495.

16 See R. K. Emmerson, The Apocalyptic Imagination in Medieval Literature, reviewed in Church History 64 (1995): 466-9.

17 Montaigne, Essays, I, 21, The Complete Works of Montaigne, ed. D. Frame, (Stanford: Stanford UP, 1957) 68.

18 Ibid., Essays, III, 13, “Of Experience," 821-2.

19 Ibid., 836.

20 'To compose our character is our duty, not to compose books, and to win, not battles and provinces, but order and tranquility in our conduct. Our great and glorious masterpiece is to live appropriately.' Montaigne, Essays, 'Of Experience,' 850-51.

21 On the Duty of Man and Citizen According to Natural Law, ed. James Tully, trans. Michael Silverthorne (Cambridge: Cambridge UP, 1991) xvi-xvii.

22 Ibid., xvii. 
23 David Hume, The History of England from the Invasion of Julius Caesar to the Revolution in 1688, 6 vol. (Indianapolis: Liberty Press, 1983) VI, lxii:153.

24 Leviathan, ed. Richard Tuck, rev. student ed. (Cambridge: Cambridge UP, 1996) 15-16.

25 David Johnston, The Rhetoric of Leviathan: Thomas Hobbes and the Politics of Cultural Transformation (Princeton: Princeton UP, 1986) 19.

26 Adam Smith, letter to Gilbert Elliot, October 10th 1759, The Correspondence of Adam Smith, ed. E. C. Mossner and I. S. Ross, rev. ed. (Oxford: Oxford University Press, 1987) 51. Further references to this work will be included in parentheses within the text.

27 'Of the External Senses,' Essays on Philosophical Subjects, 60:156. The essay has not been conclusively dated, but is thought by the editors to be quite early: see 15, 133-4. Future references to this work will be included in parentheses within the text.

28 Treatise I, I, IV:12.

29 Douglas G. Long, Bentham on Liberty (Toronto: University of Toronto Press, 1977), 17.

30 Hume died in 1776, the year in which Bentham's Fragment on Government appeared. Hume could not have known of, or formed any comprehensive judgment of, Bentham's system.

31 Mill on Bentham and Coleridge, intro. F.R. Leavis (London: Chatto \& Windus, 1971) 61.

32 Analysis of the Phenomena of the Human Mind, 2nd edition, 2 Vols., 1869 (New York: Kelley Reprints, 1967) I, VII:245, n77. 